\title{
Prevention of Children Obesity: A Nutrition Education Intervention Model on Dietary Habits in Basic Schools in Chile
}

\author{
Fernando Vio*, Gabriela Fretes, Edith Montenegro, Carmen Gloria González, Judith Salinas \\ Institute of Nutrition and Food Technology (INTA), University of Chile, Santiago, Chile \\ Email: ${ }^{*}$ fio@inta.uchile.cl
}

Received 3 June 2015; accepted 25 October 2015; published 28 October 2015

Copyright (C) 2015 by authors and Scientific Research Publishing Inc. This work is licensed under the Creative Commons Attribution International License (CC BY). http://creativecommons.org/licenses/by/4.0/

(c) (7) Open Access

\begin{abstract}
The objective of this study is to describe the process and results of a three-year project designed to create a nutrition education intervention model that promotes healthy dietary habits among teachers, students and their families. The methodology consisted in surveys, focus groups and Delphi method to assess teachers', students' and parents' dietary habits, followed by an intervention for parents, and a participative nutritional education intervention with information and communication technologies applied to teachers, with the purpose to transfer nutritional knowledge and habits to school children and their families. Qualitative results were measured in all the phases of the project with positive results, and quantitative results demonstrated significant changes in food knowledge and healthy dietary habits in parents, teachers and students, compared with the control groups, without changes in students' nutritional status during the short period of the intervention. With the results, an integral school nutrition education model in healthy eating was developed with children, parents, teachers and support for school management. This model should be applied in the educational sector to address the problem of unhealthy diet and childhood obesity that affects Chile and the world.
\end{abstract}

\section{Keywords}

Nutrition Education, School Health, Obesity Prevention, Dietary Habits, Public Health Policy

\section{Introduction}

Given the increase in childhood obesity in Chile and around the world [1] [2], there is consensus among researchers, educators, health workers and political authorities regarding the urgent need to introduce the subjects

"Corresponding author.

How to cite this paper: Vio, F., Fretes, G., Montenegro, E., González, C.G. and Salinas, J. (2015) Prevention of Children Obesity: A Nutrition Education Intervention Model on Dietary Habits in Basic Schools in Chile. Food and Nutrition Sciences, 6, 1221-1228. http://dx.doi.org/10.4236/fns.2015.613128 
of diet and nutrition into schools to educate children and their families in healthy eating habits. The objective of this effort is to prevent obesity and improve health and quality of life during adulthood. Schools and teachers in particular are considered key agents in promoting healthy eating in the school community, while everyday school activities are seen as important to developing healthy lifestyles, not just among students and their teachers but in families and communities as well. There exists broad recognition of the importance of intervening in the first stages of life to generate cultural change, encourage formation of healthy habits, and build foundations of good health and quality of life.

Educational institutions need appropriate teaching methodologies and materials to address this topic. Education about nutrition requires innovative strategies and simple and cost-effective interventions that integrate the spheres of school, family and community using a participative method which involves all members [3].

Nutritional epidemiological studies have shown that knowledge acquired through nutrition education programs, even when directed at a population that is aware, wants to receive information and is open-minded, and it is rarely put into practice. Therefore, such knowledge does not translate into healthy dietary habits and practices that are consistent with the recommendations received [4].

Teachers are an essential part of the school community, responsible for transferring knowledge and developing skills and attitudes among their students through participative and active teaching methods [5]. This is the basis for carrying out an applied research project aimed at developing healthy dietary habits among preschool and primary school children, and from that, to create a pedagogical model through which teachers can transfer knowledge about healthy eating habits to the students and their families [6]. The objective of this study is to describe the process and results of a three-year project designed to create a nutritional education intervention model that promotes healthy dietary habits among teachers, students and their families.

\section{Methods and Results}

\subsection{Surveys}

To understand the nutritional situation in schools, surveys were applied to measure dietary knowledge and food consumption among children, parents and teachers during the first year of the project [7]. For the children, a survey used in a previous study [8] was adapted, adding illustrations of food that could be easily understood. One version with 15 questions (5 about knowledge and 10 regarding consumption) was developed for pre-school children while another was developed for first and second graders that contained 13 questions (5 about knowledge and 8 about consumption). A survey that had been applied in a previous study on nutrition education in primary schools in Chile [9] was adapted and applied to the parents and teachers. The same variables were maintained in these surveys, with the addition of questions about daily consumption of bread and water and the number and type of meals during the day. The parents were also asked about the eating habits of their children.

The population surveyed consisted of 150 children, 120 parents and 12 preschool and primary school teachers (pre-school, first and second grades) in public schools in Santiago, Chile. The statistical methodology was described in a previous paper [7].

The surveys revealed that the children had excellent knowledge about healthy eating, with adequate consumption of these products. The parents, on the other hand, despite having adequate knowledge, consumed very unhealthy food, as do the teachers. Regarding eating habits during the day, dinner was replaced by a non-healthy snack at tea time. Here there was a significant difference between parents of pre-school students and parents of first and second graders: a greater percentage of pre-school parents report eating dinner (a healthier behavior), a habit that is lost once the children move into first grade. In terms of money, preschool parents do not give their children money to buy snacks, revealing that there is greater concern for the healthy eating of smaller children. This behavior is also lost when the children enter primary school.

\subsection{Focus Groups}

Eight focus groups were held with teachers, distributed over a total sample of 50 subjects, with intentional sampling [10]. The groups were divided by educational level: 4 focus groups were held with pre-school teachers and 4 were held with primary school teachers. In addition, there were 6 focus groups with parents, distributed over a sample of 53 participants. Like the teachers, the focus groups were divided by the two educational levels (3 groups for each level). Information collection practices followed a moderator's guide containing the various 
subjects to be studied. Each session was recorded and transcribed for subsequent data analysis using a content analysis technique to identify the most frequent statements and core ideas [11].

\subsubsection{Teachers}

The teachers felt highly motivated to apply a healthy eating program to their students, given that several activities related to these topics had been carried out previously. It was observed that children of that age are fairly receptive, particularly when the activities are fun. The most frequent discourse was the need to include the entire school community (children, parents, teachers, administrators), highlighting the important role of parents in changing children's habits. The barriers they mentioned were low participation of parents and the need for training in nutrition. Expectations about the program were related to its continuity throughout the school year and whether it can be presented in a broad way to different learning subsectors.

\subsubsection{Parents}

The parents expressed that they found it difficult to form good habits in their children due to the lack of time they have to dedicate to them, as life has become more complex and eating does not have the importance it once did. The parents also manifested misconceptions about what constitutes a healthy diet with statements such as "healthy food is expensive, it doesn't taste good, preparing it is more difficult, it is boring". Among the difficulties related to maintaining a healthy, balanced family diet were the lack of rules and information within the household, powerful advertising of unhealthy foods and the fact that today, parents are working longer hours and spending less time at home, delegating compliance with rules to caretakers who often don't adhere as strictly to the rules established by parents. Parents were motivated by the opportunity for their children to learn about healthy eating, recognizing that the change must begin with them. The majority of the parents were willing to make changes, but they had concerns because it is difficult to replace old habits with healthy ones. They expressed interest in receiving information such as meal recipes, advice on shopping for healthy food and how to read product labels, information about appropriate meal sizes by age and food properties, among others.

\subsection{Delphi Method}

Based on the results of the surveys and focus groups, it was necessary to get consensus on the main topics related with nutrition education on healthy diet at schools. For that purpose, experts in the areas of nutrition, education and communication were consulted using the Delphi mixed technique of consensus [12]. This is a qualitative research method used to reach consensus among panels of experts, through iterations or repetitive rounds (usually via email) of anonymous opinions on statements made by the group moderator about educational materials and methodologies to encourage healthy eating [13]. The method was structured in three stages: in the first stage the project researchers developed the questionnaire based on results from the surveys and focus groups. In the second stage, the experts were selected and an email request was sent asking them to participate in the project. Those who accepted were sent the first-round survey and organized into a hierarchy and priorities about methodologies and materials that should be utilized. In the third stage, the experts were sent a new, secondround questionnaire with results from the first round. In the second round, they could change their opinions upon learning of the responses from other members of the group. Finally, with consensus about the main subjects that should be addressed by the new educational material, the content was validated by two groups of 10 parents each and in two groups of teachers, one with 11 participants and the other with 12 participants, as described by Ziemendorf [14].

There was a consensus on promoting audiovisual educational materials rather than written ones, particularly television spots and short videos and making use of Information, Communication Technologies (ICT). In terms of methodologies, participatory activities were given priority over passive ones. For children, the priority activities were cooking, playing, recreational activities and educational messages through local communication channels or social media. Parents were reached through contests, fairs, cooking presentations, healthy activities in public spaces, group celebrations and activities at school, in the neighborhood or community, and at places where food is sold. The channels used for teachers are workshops on self-care and healthy living, cooking classes and educational messages provided through the media and the Internet.

There was also consensus about the need to strengthen work with families in terms of providing recommendations about family diet, such as choosing healthy, homemade food rather than processed food, restricting candy consumption and snacking, eating together as a family and turning off the TV at mealtimes, eating dinner at 
night rather than an unhealthy snack, how to choose and prepare healthy food, educating children about food sold at malls, restaurants and street stands, how to save money by purchasing healthy food and how to associate recreational activities with healthy eating.

This Delphi methodology provided the results essential for preparing the final design of the healthy eating educational model for preschool and primary school students, their parents and teachers, in order to change today's poor dietary habits.

\subsection{Cooking Workshops with the Families}

Cooking workshops with 27 families of children attending public schools in the Macul district of Santiago, Chile, were carried out compared with a control group [15]. At the start and the end of the intervention, a validated survey [16] was applied to each child and their parent regarding consumption of fruit, vegetables and fish including food knowledge, attitudes and family eating habits. The intervention targeted parents and consisted of six 90-minute cooking workshops that included videos [17] and photovoice [18]. The topics addressed in the workshops were related to healthy eating, preparation of healthy breakfasts, lunches and dinners; the importance of eating together as a family, why it is necessary to eat five portions of fruit and vegetables every day, the benefits of eating fish for cardiovascular health and how to shop for healthy food. The activities were led by a nutritionist, with support from a culinary expert. Qualitative methods were used to evaluate the educational intervention process as a pedagogical model. Initial, monitoring and final personal opinion surveys were used to measure the participants' satisfaction with the methodology, content and organization of the workshops, changes in family eating habits, expectations about what they would learn, and other topics. In addition, attendance was taken at the workshops. Those who attended at least $60 \%$ of the workshops were considered to have been subject to the intervention.

The results showed that the parents had an excellent level of knowledge about healthy food; however, consumption of fruit, vegetables and fish at the start of the intervention was low in both groups. The children also had low intake of those foods, mainly of vegetables and fish. At the end of the intervention, consumption of fruit, vegetables and fish among parents in the intervened group substantially improved. Like the parents, the children in the intervention group consumed more fruit, vegetables and fish than those in the control group. All of the families who attended the workshops made some change to their dietary habits, such as greater consumption of fruit, vegetables and fish, eating healthy breakfasts, more organized eating habits and appropriate portion sizes. In $45.5 \%$ of the households, there were no difficulties encountered in implementing dietary changes. The difficulties described by some parents were related to money, time and preferences for certain types of food.

\subsection{Food and Cooking Workshops with Teachers}

A nutritional education intervention was applied to 25 preschool and primary school teachers, to transfer knowledge about nutrition to the students. This intervention was conducted in two cities, Los Andes (experimental school) and San Felipe (control school) in the Valparaíso Region of Chile. The study lasted for the duration of the school year, with a before and after evaluation of students compared to the control group. The methodology, sample size and results are described elsewhere [19] [20].

Nine workshops were held to the teachers on different subjects related to diet and nutrition: nutritional evaluation, special diets and healthy snacks, meal distribution, healthy breakfast, lunch, tea time and dinner, nutritional labeling, use of ICT and shopping of healthy food. The topics were chosen by the teachers and the workshops were planned and led by a nutritionist and a chef who participated in the cooking workshops. The knowledge acquired by the teachers was transferred to the students in the classroom and through curriculum materials, supervised by the nutritionist. In addition, extracurricular activities were held to integrate families into the project. These included the performance of a play, a presentation of healthy meals for family day, and practical activities in parent meetings.

To evaluate the effects of the intervention, a validated survey about knowledge and intake in children was applied [8]. Besides, anthropometric measurements of weight and height were taken of all the pre-school through second grade students. As in the parent workshops, the intervention with teachers was evaluated using qualitative methods that included initial, monitoring and final surveys of personal opinion. Attendance at these workshops was also recorded and teachers who attended at least $60 \%$ of the workshops were considered to have been subject to the intervention. 
All of the teachers agreed that what they learned in the healthy eating workshops was very useful for their daily lives and for transferring knowledge to students (both items were given the maximum score of 5). The strategies most frequently used to transfer knowledge to students were supervision of snacks, audiovisual resources and in-class conversations. Used to a lesser extent were nutritional labeling, incentives to eat fruit and vegetables, physical activity and mobility workshops, and the incorporation of content into teaching materials for the natural sciences and visual arts.

There were no significant changes in the nutritional status of the total intervention group compared to the control school. Knowledge about all aspects of healthy eating increased significantly in the intervened schools, while at the control school, knowledge only improved in regard to eating fish and salads-legumes. In terms of consumption, there was a significant drop in consumption of all unhealthy food at the intervened schools, while consumption of healthy food remained stable. On the other hand, at the control school consumption of unhealthy food remained stable, while consumption of vegetables and legumes decreased significantly [19] [20].

All the activities of the three year project were approved and supervised by the Institute of Nutrition and Food Technology Ethical Committee.

The figure below provides a summary of the activities carried out during the three years of the project implementation (Figure 1).

\section{Development of the Educational Model}

With the results from the surveys, focus groups, consultation with experts and the interventions, an integral educational model for a healthy eating was developed in three spheres of action: workshops with teachers and students, workshops with parents and guardians and support for school management (Figure 2).

The aim of this model is to improve healthy eating knowledge, skills and practices at school and promote attitudes, behavior and habits for healthy eating among children and their families [21]. For teachers, workshops
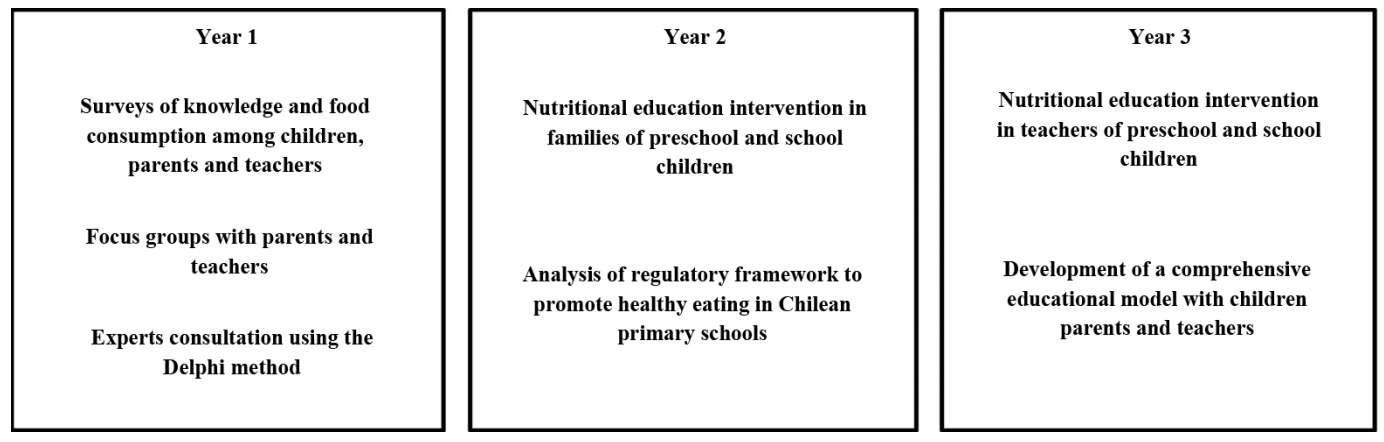

Figure 1. Activities during the three year project implementation.

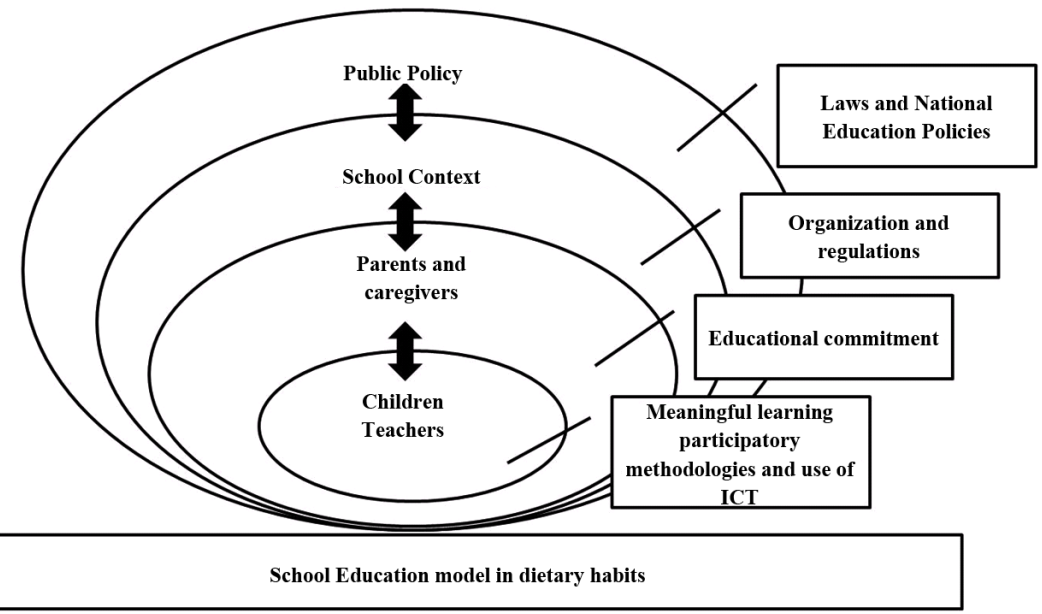

Figure 2. School education model in dietary habits. 
were proposed on different subjects chosen by a consensus between the teachers and the nutritionist related to nutrition and diet, with the participation of a nutritionist and a chef. The knowledge acquired by the teachers should be transferred to the students in the classroom and through curriculum materials, supervised by a nutritionist. For parents, workshops should be flexible according to the difficulties of time described by some parents, and taking into account barriers related to money and preferences for certain types of food. The nutrition education process requires the support from the school system to address important issues related with healthy food, such as infrastructure, food provided by the school lunch program, snack consumption at the break time, school regulations about food consumption and a number of school activities related with food. The subjects of the participative educational actions are teachers and parents, who can then transfer the content to their students and children at school and at home, through daily activities related to eating. This must be supported by clear internal rules at schools [22]. The institutional support component reinforces the healthy eating content and the knowledge transfer to children by parents and teachers, through organizational and infrastructure changes needed at the schools. These provide consistency with the educational messages, children's experiences and the environments that influence childhood development and learning.

\section{Discussion}

One the most important findings in this study was the understanding that students, parents and teachers know what a healthy diet is, but fail to put it into practice. The exception is among children in pre-school, as parents of those children were concerned about providing them with healthy food in the evening and did not give their children money to buy sweets. It was also important to recognize their interest in incorporating healthy eating topics into the educational process and their willingness to make changes. There was a consensus among parents, teachers and experts about the need to use participative and innovative methodologies, particularly the use of ICT and practical workshops on cooking, reading labels and shopping for food, to increase knowledge about healthy eating. These methods were used in the cooking workshops with the families, verifying the difficulty parents encountered in attending the sessions regularly due to lack of time or other barriers. However, those who did attend made significant changes in their dietary habits and practices [15]. In this sense, in other interventions it has been observed that community commitment and organization are important factors that must be considered when evaluating the success of a project of this type, to ensure that the changes made are maintained over time [23] [24].

In the food and cooking workshops with teachers, the participative method with use of ICT was utilized to encourage them to transfer knowledge and habits to their students through the curriculum, but mainly in relation to snacks and other activities related to diet. Other interventions with teachers requires that they must be educated and become aware of the effect of their behavior [25] because they do not always act according to their beliefs in the pedagogic meal situation [26] [27].

There were no changes in nutritional status because of the short period of the intervention and in Chile's nutrition situation, where overweight and obesity are increasing [28], but knowledge and healthy food consumption improved in the experimental group. These results are similar to other studies where obesity was not reduced despite diet and nutrition education interventions improved knowledge and healthy diet [29]-[31]. For all these changes, institutional support through educational management, rules and regulations related to the school food program, the intake of high-caloric density snacks during recess in kiosks [32] and other food intake in school activities should be established, in consensus with parents and caregivers [33].

\section{Conclusion}

The project findings should be applied in the educational sector to address the problem of childhood obesity that affects Chile and many other countries around the world. Without an educational intervention in schools that encompasses the entire educational community (teachers, student, parents and school headmasters and authorities), it is very hard to obtain positive results. Further research on this topic that incorporates parents, teachers and children is needed to continue making progress, as the major challenge that remains is how to include the entire family in changing dietary habits.

\section{Funding}

This study was supported by the National Fund for Scientific and Technological Development, FONDECYT 
[grant number 1140748] from the Chilean National Council for Science and Technology (CONICYT).

\section{References}

[1] Swinburn, B.A., Sacks, G., Hall, K.D., et al. (2011) The Global Obesity Pandemic: Shaped by Global Drivers and Local Environments. Lancet, 378, 804-814. http://dx.doi.org/10.1016/S0140-6736(11)60813-1

[2] Rivera, J.A., González de Cossio, T., Pedraza, T., Aburto, C., Sánchez, T.G. and Martorell, R. (2014) Childhood and Adolescent Overweight and Obesity in Lati America: A Systematic Review. The Lancet/Diabetes-Endocrinology, 2, 321-332. http://dx.doi.org/10.1016/S2213-8587(13)70173-6

[3] Hawkes, C., Smith, T.G., Jewell, J., Wardle, J., Hammond, R.A., Friel, S., Thow, A.M. and Kain, J. (2015) Smart Food Policies for Obesity Prevention. The Lancet Series, 1, 1-12. http://dx.doi.org/10.1016/s0140-6736(14)61745-1

[4] Flórez-Alarcón, L., Durán Strauch, E., Eslava, J.C., et al. (2006) Tres Estudios de Análisis de las Actividades de Salud Escolar y de las Condiciones Organizacionales Asociadas, en Escuelas Distritales de Bogotá. TIPICA, Boletín Electrónico de Salud Escolar, 2, 1.

http://scholar.google.cl/scholar?q=1.+childhood+and+adolescent+overweight+and+obesity+in+lati+america:+a+syste matic+review\&hl=en\&as_sdt=0\&as_vis=1\&oi=scholart\&sa=X\&ei=8mJnVYjOGsOYgwS03oH4AQ\&ved=0CBsQgQ MwAA9

[5] Perez Villasante, L. and Raigada Mares, J. (2008) Efectividad de un programa educativo en estilos de vida saludables sobre la reducción de sobrepeso y obesidad en el Colegio Robert M. Smith; Huaraz, Ancash, Perú. Acta Médica Peruana, 25, 204-209.

[6] Durá Travé, T. and Sánchez-Valverde Visus, F. (2005) Obesidad infantil: ¿un problema de educación individual, familiar o social? Acta Pediátrica Española, 63, 204-207.

[7] Vio, F., Salinas, J., Lera, L., González, C.G. and Huenchupán, C. (2012) Conocimiento y consumo alimentario en escolares, sus padres y profesores: Un análisis comparativo. Revista Chilena de Nutrición, 39, 34-39. http://dx.doi.org/10.4067/S0717-75182012000300005

[8] Olivares, S., Bustos, N., Moreno, X., Leyton, B., Durán, R. and Vio, F. (2006) Actitudes y prácticas sobre alimentación y actividad física en niños obesos y sus madres en Santiago. Chile. Revista Chilena de Nutrición, 33, 170-179. http://dx.doi.org/10.4067/S0717-75182006000200006

[9] Olivares, S., Morón, C., Zacarías, I., Andrade, M., Kain, J., Lera, L. and Vio, F. (2003) Educación en nutrición en las escuelas básicas de Chile. Food, Nutrition \& Agriculture (FAO), 33, 64-69.

[10] Krueger, R.A. (1988) Focus Groups. A Practical Guide for Applied Research. Sage Publications, Inc., USA.

[11] Navarro, P. and Díaz, C. (1993) Content Analysis. In: Delgado, J.M. and Gutiérrez, J., Eds., Quantitative Methods and Techniques for Research in Social Sciences, Madrid.

[12] Vio, F., Lera, L., Fuentes-García, A. and Salinas, J. (2012) Método Delphi para identificar materiales educativos sobre alimentación saludable para educadores, escolares y sus padres. Archivos Latinoamericanos de Nutrición, 62, 275-282.

[13] Bloor, M. and Wood, F. (2006) Keywords in Qualitative Methods. Sage Publications, Inc., London.

[14] Ziemendorf, S. and Krause, A. (2003) Guía de validación de materiales educativos (con enfoque en materiales de educación sanitaria). Primera Edición. Programa de Agua y Saneamiento PROAGUA/GTP, Chiclayo.

[15] Fretes, G., Salinas, J. and Vio, F. (2013) Efecto de una intervención educativa sobre el consumo de frutas, verduras y pescado en familias de niños prescolares y escolares. Archivos Latinoamericanos de Nutrición, 63, 37-45.

[16] Lera, L., Salinas, J., Fretes, G. and Vio, F. (2013) Validación de un instrumento para evaluar prácticas alimentarias en familias chilenas de escolares de 4 a 7 años. Nutricion Hospitalaria, 28, 1961-1970.

[17] Banks, M. (2010) Métodos visuales e investigación de campo. In: Banks, M., Ed., Los datos visuales en investigación cualitativa, Ediciones Morata, Madrid.

[18] Wang, C. and Burris, M.A. (1997) Photovoice: Concept, Methodology and Use for Participatory Needs Assessment. Health Education \& Behaviour, 24, 369-387. http://dx.doi.org/10.1177/109019819702400309

[19] Vio, F., Salinas, J., Montenegro, E., González, C.G. and Lera, L. (2014) Efecto de una intervención educativa en alimentación saludable en profesores y niños prescolares y escolares de la región de Valparaíso, Chile. Nutricion Hospitalaria, 29, 1298-1304.

[20] Montenegro, E., Salinas, J., Parra, M., Lera, L. and Vio, F. (2014) Evaluación de una intervención de educación nutricional en profesores y alumnos de prebásica y básica de la comuna de Los Andes en Chile. Archivos Latinoamericanos de Nutrición, 64, 182-191.

[21] Salinas, J., González, C.G., Fretes, G., Montenegro, E. and Vio, F (2014) Bases teóricas y metodológicas para un programa de educación en alimentación saludable en escuelas básicas de Chile. Revista Chilena de Nutrición, 41, 343-350. 
http://dx.doi.org/10.4067/S0717-75182014000400001

[22] Salinas, J., Correa F. and Vio, F. (2013) Marco normativo para promover una alimentación saludable en escuelas básicas de Chile. Revista Chilena de Nutrición, 40, 274-282. http://dx.doi.org/10.4067/s0717-75182013000300010

[23] Wrieden, W.L., Anderson, A.S., Longbottom, P.J., Valentine, K., Stead, M., Caraher, M., Lang, T., Gray, B. and Dowler, E. (2007) The Impact of a Community-Based Food Skills Intervention on Cooking Confidence, Food Preparation Methods and Dietary Choices-An Exploratory Trial. Public Health Nutrition, 10, 203-211. http://dx.doi.org/10.1017/S1368980007246658

[24] Garcia, A.L., Vargas, E., Lam, P.S., Smith, F. and Parrett, A. (2013) Evaluation of a Cooking Skills Programme in Parents of Young Children-A Longitudinal Study. Public Health Nutrition, 17, 1013-1021. http://dx.doi.org/10.1017/S1368980013000165

[25] Osowski, C.P., Göranzon, H. and Fjellström, C. (2013) Teacher's Interaction with Children in the School Meal Situation: The Example of Pedagogic Meals in Sweden. Journal of Nutrition Education and Behavior, 45, 420-427. http://dx.doi.org/10.1016/j.jneb.2013.02.008

[26] Nahikian-Nelms, M. (1997) Influential Factors of Caregiver Behavior at Mealtime: A Study of 24 Child Care Programs. Journal of the American Dietetic Association, 97, 505-509. http://dx.doi.org/10.1016/S0002-8223(97)00130-2

[27] Sepp, H., Abrahamsson, L. and Fjellström, C. (2006) Pre-School Staffs' Attitude towards Foods in Relation to the Pedagogic Meal. International Journal of Consumer Studies, 30, 224-232. http://dx.doi.org/10.1111/j.1470-6431.2005.00481.x

[28] JUNAEB (2015) Mapa Nutricional de Chile.

[29] Kain, J., Leyton, B., Concha, F., Weisstaub, S.G., Lobos, L., Bustos, N. and Vio, F. (2012) Evaluación de una intervención en educación alimentaria y actividad física para prevenir obesidad infantil en escuelas públicas de Santiago de Chile. Archivos Latinoamericanos de Nutrición, 62, 60-67.

[30] Lobos, L., Leyton, B., Kain, J. and Vio, F. (2013) Evaluación de una intervención educativa para la prevención de la obesidad infantil en escuelas públicas de Chile. Nutricion Hospitalaria, 28, 1156-1164.

[31] Constant, P. and Locke, K. (2009) Do School Based Food and Nutrition Policies Improve Diet and Reduce Obesity? Preventive Medicine, 48, 45-53. http://dx.doi.org/10.1016/j.ypmed.2008.10.018

[32] Bustos, N., Kain, J., Leyton, B. and Vio, F. (2011) Cambios en el patrón de consumo de alimentos en escolares chilenos con la implementación de un kiosko saludable. Archivos Latinoamericanos de Nutrición, 61, 302-307.

[33] Tucker, P., Irwin, J.D., He, M., Sangster, L.M. and Pollet, G. (2006) Preschoolers’ Dietary Behaviours: Parents’ Perspectives. Canadian Journal of Dietetic Practice and Research, 67, 67-71. http://dx.doi.org/10.3148/67.2.2006.67 